\title{
The Preservation of Fibre Ropes for Use in Sea-Water.
}

\author{
By \\ W. R. G. Atkins, Sc.D., F.R.S., \\ Head of the Department of General Physiology at the Plymouth Laboratory, \\ and \\ J. Purser, M.A., B.A.I., \\ Professor of Civil Engineering in the University of Dublin.
}

EXPERIENCE gained in the preservation of fishing nets and lines has led to the study of various methods of preserving ropes when immersed in seawater. In normal use a rope deteriorates partly from wear and tear, partly from the destruction of its fibres by bacterial action. Which of the two is most severe depends upon the conditions under which the rope is used. The internal friction of the rope is much reduced and its useful life prolonged by the incorporation of a lubricant, which according to the United States Government specifications should be not less than 8 and not more than 12 per cent of the weight of the rope as sold. When ropes are wet, or even damp, bacterial action proceeds far more rapidly than when they are dry. Once a rope has been wetted by sea-water it is nearly always damp. Ropes may even become entirely useless while in store below decks, especially in tropical climates. The use of a proper preservative can completely stop all decay. The result that follows from this is twofold; firstly the rope lasts longer, risk of failure in service is reduced and the cost of the labour and material required for renewals is lessened; secondly, since one knows that the rope will maintain a figure close to its original strength for far longer, it may be possible in certain cases to use ropes of a lesser initial strength.

The destructive action of bacteria is far greater in dirty water than in clean water. Consequently tests have been carried out in both. The tests carried out in Plymouth Sound were exceptionally severe, since the water was at times contaminated by drainage from the Pier, under which the ropes were exposed; the site is also downstream and not very far away from the main sewer outfall of Plymouth, but not in the direct line of flow from this. The ropes were clamped at one end between three-inch strips of wood screwed together. These strips were tied to the iron columns of the pier at first by galvanized iron wire, later by galvanized steel wire after one set had been lost in a storm. The position of the ropes was such that they were hanging clear of the water for about four hours 
each tide. The ends were bound with twine so as to prevent unlaying. The ropes were subjected to the action of strong tidal currents and to considerable wave action in rough weather.

The exposures made under the pier were with ropes approximately two inches in circumference, three or four strand. Further exposures were made in an enclosed fish pond at Cawsand, just outside the Breakwater of Plymouth Sound, where the water was much clearer and rose and fell freely with the tide. Only when the accumulated seaweed was rotting in October-November was this water dirty. The ropes at Cawsand were always immersed.

\section{Fibre Ropes used.}

The terminology of the rope industry appears to be vague. Hemp fibre was most used formerly, so everything else is called hemp by some. The " hemp rope department " of one large firm supplied us with a hemp rope which proved not to be hemp at all but manila fibre. We speak of fibre ropes to distinguish them from metal ropes, which have nevertheless a fibre core in many cases, the preservation of which is most important. The preservatives adhere differently to the various fibres so their identification is necessary.

The fibres used were as follows :-

(a) Hemp fibre, derived from the bast of the stem of the hemp plant, Cannabis sativa, produced mainly in Russia and Italy.

(b) Manila fibre, derived from the sheathing leaf-stalks of Musa textilis, a plant of the banana family; it is produced almost exclusively in the Philippine Islands.

(c) Sisal fibre, derived from the leaves of Agave sisalana Perr., a native of Central America now grown largely in East Africa.

(d) Coir, the fibre of the coco-nut.

\section{Method of testing the Tensile Strength of Ropes.}

The mechanical tests of the rope specimens were carried out in the 10-ton Buckton Vertical Testing Machine in the Engineering Laboratory of Trinity College, Dublin University.

Owing to the short length of the specimens it was not possible to grip the ends in a way likely to avoid all damage. Various tests were made on rope similar to that used in the tests and eventually in the light of these it was decided to proceed as follows. Each specimen, one yard in length, was cut into two. The ends of each piece were partially unlaid and a 6 -inch round wire nail was pushed into the rope endwise. The strands were then laid up tightly again and the ends served with fine twine. The 
end six inches of each piece were then soaked in glue for about an hour. This left a thick coating of glue on the ends and partially protected the outer fibres from the serrations of the grips.

It was thought that two results from each specimen, even if not giving a perfect test, would at least give comparable results ; those of 12 tests on a 2-inch yacht manila of good quality are shown in Table 1.

\section{TABLE 1.}

To test the reliability of method of testing 2-in. yacht manila rope; breaking load given in pounds. Break at nail end, $\mathrm{N}$, or at grip edge, G.

$\begin{array}{cccrcc}\text { No. } & \text { Lb. } & \text { Break. } & \text { No. } & \text { Lb. } & \text { Break. } \\ 1 & 5840 & \text { N } & 7 & 5250 & \text { N } \\ 2 & 5390 & \text { N } & 8 & 4470 * & \text { N } \\ 3 & 5260 & \text { G } & 9 & 5590 & \text { N } \\ 4 & 5250 & \text { N } & 10 & 5310 & \text { N } \\ 5 & 5730 & \text { N } & 11 & 5400 & \text { G } \\ 6 & 5500 & \text { G } & 12 & 5650 & \text { G }\end{array}$

None of the pieces broke in the centre clear of the nails or grips, but the average strength is about $2 \cdot 4$ tons which is considerably in excess of the British standard's specification requirement, so that it may be assumed with some reason that the method of testing is moderately satisfactory. It will be noticed that the average strength of the three pieces that failed at the grip edge is the same as that of the eight pieces that failed at the nail end, namely, $5470 \mathrm{lb}$. each.

Slight chafing of the fibres was seen at the nail ends, but this really amounted to little more than bruising and it does not seem that the effect of the nail end was different from that of the grips. There was slight bending at this point, but the nail had a long tapering point and the bending stresses must have been small. There are several examples among the treated and exposed ropes which show that the strength of a specimen which failed at the grip or nail end was greater than that of its duplicate which failed clear of nail or grip. Seven such cases occurred in tests on hemp rope, two on yacht manila and two on coir.

In view of the variations to be expected in tests on ropes the above results seem to show that the method of testing is sufficiently good to enable the results to be relied upon for approximate comparisons. More exact results would have been obtained had the samples been more numerous and of greater length.

The tensile tests on the six-strand yacht manila rope, about $0 \cdot 6$ in. circumference, were carried out by making a loop passing over the hook of a spring balance, each piece being a yard in length. This served up to $200 \mathrm{lb}$. tensile strength. For those above $200 \mathrm{lb}$. we are indebted to Major 
Hambling, Engineering Dept., of Devonport Technical College, for his assistance ; these were tested by suspending weights from a hook attached by a loop in the thin rope. The breaks did not occur at the loop.

\section{Substances used in Preservation of Ropes.}

These have been fully described in the accompanying paper (pp. 627630 ) on net preservation. The completely volatile solvents used were petrol, paraffin, benzene and two "Coalite " products of low temperature distillation, namely, the neutral oil b.p. $100-245^{\circ}$ C., which has been previously extracted with strong alkali to remove phenolic compounds, and " oil A," which has had an extra extraction with acid to remove basic sulphur and other basic compounds. The more highly purified product is no better as a solvent as may be seen from the results of Table 3, but it does not darken on standing, so that ropes treated with a green copper soap alone appear a pleasing green instead of a dirty brown; when, however, tar is also used in the mixture this point is obviously of no importance.

A variety of coal tars and oils have been tried, including those produced by the Coalite process. Since these have not as yet been fully absorbed in industry they are still relatively cheap. Hardwood tar (Shalco) was also tried, and softwood tar (Stockholm), but the latter is somewhat expensive. Though better than hardwood tar the pleasant odour of the pinewood tar and its customary use are its chief recommendations, together with the fact that both the wood tars dry more rapidly and more thoroughly than the coal tars. The copper soaps were obtained as follows: naphthenates from the Cuprinol and Shell Companies, oleate and resinate from Wm. Bailey \& Sons, Wolverhampton; samples were kindly presented by these firms, also Shalco tar by Messrs. Shirley, Aldred \& Co., Worksop, and Coalite products by the works at Gawber, Yorkshire.

The substances used in preserving ropes add somewhat to their weight in air, but many of them occupy interstices which would otherwise hold water, when wet, so in reality very little is added to the weight of the rope. It must be remembered also that an organic solvent may dissolve out a certain amount of the lubricant, 8-12 per cent by weight, incorporated in the rope. Quite apart from the preservation of the rope against bacterial attack it is therefore highly advisable to select a preservative which will act as a lubricant also. The tars and tar oils will have some such action, but copper oleate and the copper naphthenate of Cuprinol and the Shell preservatives are good lubricants ; copper resinate on the other hand is a dry powder with no such action. The various cutching processes, too, may be expected to leave a dry lifeless rope. These facts must be remembered when judging the most suitable preservative for any particular purpose. 
Thus for prolonged immersion in the sea the highly effective heavy tars with copper soaps are desirable, whereas where immersion is not continuous or possibly where conditions are only occasionally wet an effective lubricant is the first consideration.

Cost is also an important item; some of the proprietary compounds are comparatively expensive, though the great saving in loss of ropeand possibly the loss of what it serves to secure - must be borne in mind. Nevertheless some of the mixtures tried here may be considered as having merits on the score of lower cost; this is especially true of the Coalite solvent and of the tar mixtures, except Stockholm tar. It is the solvent that contributes most to the price of the mixture since the copper soaps used are only about $12-18$ pence per pound.

The mixtures tried were obtained as a rule by adding even pounds to a gallon of solvent; for water this gives a 10 per cent solution, but for benzene, sp. gr. about $0 \cdot 8$, it is over 12 per cent. Allowing, however, for the fact that a pound of tar or of a melted copper soap is never all put in, and that with $1 \mathrm{lb}$. of tar the volume is over a gallon, the mixtures made as above have been termed 10 per cent solutions in the tables irrespective of their exact composition.

\section{Discussion of RESUlts.}

The tests here described are not adequate for the detection of small differences between one method and another since the amount of rope taken only sufficed for two tensile tests, the mean of which is given in general. Where wide discrepancies were found both values are given. In some cases only one test could be made, especially with the fine rope used at Cawsand. For accurate results the mean of at least six tests should be taken. The results obtained, however, leave no doubt as to whether a method is or is not serviceable, for wide differences have been observed.

The results of Table 2 show that most of the mixtures tried gave reasonably good preservation on manila rope after one year, save two with copper resinate alone. These were tried on account of the low cost of the mixture, and later work has shown that the Coalite distillate, oil A, could have been used without benzene. This with 5 per cent of copper resinate is very cheap, the solvent being about $6 \mathrm{~d}$. per gallon at the works in bulk and the resinate added costs about the same. Including carriage the mixture would scarcely exceed 1s. 6d. per gallon. Coal tar alone was quite good on rope of this diameter, but the period is too short to bring out the benefit of the addition of a copper soap; a rope with tar only is both heavy and stiff whereas the mixture with 10 per cent each of tar and copper oleate is pliable, lighter and far cleaner to handle. It also heads the list with 72 per cent. 


\section{TABLE 2.}

Best two-inch yacht manila rope, three strand. In preservative 5 hours. Immersed under Plymouth Pier 20/4/33. Breaking load when new 4090 lb., dry.

No.

Treatment.

1, 2. Untreated

5, 6. Cuprinol green for nets, no tar. opper oleate 20 per cent in benzene, 1 vol. + oil A, 3 vols.

7, 8. Copper oleate 20 per cent in benzene, $\dot{1}$ vol. + oil $\vec{B}$,

9, 10. Copper oleate and copper resinate, 10 per cent each in oil A

11, 12. Coal tar (Corroid)

13, 14. Copper oleate and Corroid tar, 10 per cent each in benzene

15, 16. Copper resinate, 10 per cent in benzene .

17, 18. Copper resinate, 5 per cent in equal volumes of benzene and oil A
Percentage strength after months of immersion.

$4 \frac{1}{4}$ months. 12 months.

37

63

61

59

74

74

66

88

0*

$62 \dagger$

$66 \neq$

$57 \ddagger$

$70 \ddagger$

$62 \ddagger$

$72 \ddagger$

31

84

$46^{*}$

* One test only. Other figures are means of two.

+ Very good impregnation.

‡ Good impregnation.

Nos. 19-38, another manila rope series, were unfortunately washed away during a. storm, but a four-strand yacht manila rope, two inch, averaging $4645 \mathrm{lb}$. when new was. down to $23 \%$ after $6 \frac{3}{4}$ months ; colourless Cuprinol for ropes gave $66 \%$ and hardwood tar (Shalco) $63 \%$ after same period under Pier. These had 24 hrs. in preservative.

\section{TABLE 3.}

White cordage hemp rope, $2 \frac{1}{4}$ inch, three strand. In preservative 24 hours. Immersed under Pier 12/7/'33.

No. Treatment.

42A. Untreated dry control

42, 59. Untreated

43, 60. Olie's method

44, 61. Cuprinol, green for nets, no tar

45, 62. Cuprinol, colourless for ropes

46, 63. Low temperature coal tar, Coalite

47, 64. Coal tar, Corroid

48, 65. Softwood tar, Stockholm .

49, 66. Low temp. tar oil, A

50,67 . Copper oleate $10 \%$ in benzene

51,68 . Copper resinate $10 \%$ in benzene

52,69 . Copper oleate $10 \%$, Corroid tar $10 \%$ in benzene

53,70 . Copper resinate $10 \%$, Corroid tar $10 \%$ in benzene

54,71 . Cuprinol, green with $10 \%$ Corroid tar

55,72 . Coalite neutral oil b.p. $100-245^{\circ} \mathrm{C}$.

56,73 . Do. with $5 \%$ copper oleate .

57,74 . Do. with $5 \%$ copper resinate

58,75 . Hardwood tar, Shalco
Percentage strength after immersion.

$6 \frac{3}{4}$ months. 12 months. $.100(3760 \mathrm{lb}$.) $100(3430 \mathrm{lb}$.)

$\begin{array}{rr}19 & 0 \\ 25 & 0 \\ 79 & 76 \\ 44 & 33 \\ 69 & 73 \\ 64 & 78 \\ 77 & 57 \\ 29 & 0 \\ 64 & 55 \\ 87 & 52 \\ 71 & 83 \\ 89 & 57 \\ 76 & 94 \\ 27 & 0 \\ 78 & 39 \\ 50 & 30 \\ 61 & 24\end{array}$


Table 3 for hemp rope agrees with Table 2 in that this copper oleate mixture shows up well. It was however surpassed by green Cuprinol with tar, which is a marked advance on Cuprinol without tar, good as is the latter. Colourless Cuprinol for ropes, which is the zinc naphthenate, is relatively much inferior, but the mixture is a good lubricant. Again the heavy coal tars do well and the softwood (Stockholm) tar is superior to the much cheaper hardwood tar, which nevertheless did reasonably well up to almost seven months. The very cheap mixture, Coalite neutral oil with 5 per cent copper oleate, is a good lubricant and was still up to 39 per cent after a year ; this is better than the resinate.

Table 4 relates to coir rope, which when untreated keeps its strength rather better than does either manila or hemp. In this respect sisal is better still, see Table 4. But according to the more extensive comparison between sisal and manila conducted by the Imperial Institute (Bull. Imp. Inst., 1927, 25, No. 4), this varies with the quality of the fibres.

Coir being a cheap rope of lower strength than the others the aim in view was to find a reasonably effective cheap preservative. This is provided by 10 per cent copper oleate in Coalite neutral oil ; both oleate and resinate do even better in this than in oil A, the product doubly extracted, namely, by alkali and then by acid; with resinate the latter acts almost exactly in the same way as the more costly benzene. As before, the addition of 10 per cent coal tar to the copper oleate mixture would probably have been beneficial, but was not tried. Both the low temperature and ordinary coal tars do well and would do even better with the addition of 5 or 10 per cent of the copper soaps. The green Cuprinol, though good, is probably too costly for use with this rope ordinarily.

\section{TABLE 4.}

Coir rope, 2 inch, four strand with central twine. In preservative 24 hours. Immersed under Pier 12/7/'33. Breaking load when new 1120 lb., dry.

No. Treatment.

76, 86. Untreated

77, 87. Cuprinol, green for nets, no tar .

78, 88. Coal tar, Corroid

79, 89. Low temperature tar, Coalite

80,90. Softwood tar, Stockholm

81, 91. Copper oleate $10 \%$ in Coalite neutral oil b.p. 100 $245^{\circ} \mathrm{C}$.

82, 92. Do. in Coalite oil A, doubly extracted .

83, 93. Copper resinate $10 \%$ in Coalite neutral oil

84, 94. Do. in Coalite oil A

85,95 . Do. in benzene .
Percentage strength after immersion. $6 \frac{3}{4}$ months. 12 months.

$\begin{array}{rr}29 & 6 \\ 70 & 67 \\ 64 & 66 \\ 74 & 65 \\ 80 & 70 \\ & \\ 69 & 70 \\ 68 & 64 \\ 64 & 65 \\ 59 & 45 \\ 59 & 41\end{array}$


When drawing up the list of treatments for coir one very important use was overlooked. On account of its extensibility and spring this rope is much used, in great thicknesses, for joining steel rope towing hawsers. The breaking of the coir may lose a ship, yet it is certain that most of the coir towing ropes in use have deteriorated very appreciably. With a proper preservative they could be maintained near their original strength for far longer. For such purposes even the most costly preservatives are an economy.

\section{TABLE 5.}

Sisal rope, 2 inch, three strand. In preservative 24 hours. Immersed under Pier 1/3/34.

No. Treatment.

112, 96. Untreated control, dry

113, 97. Untreated

114, 98. Olie's method .

115, 99. Copper resinate $10 \%$ in benzene.

116, 100. Do. in Coalite Oil A .

117, 101. Do. in benzene with $6 \%$ Mobiloil A

118, 102. Do. with $20 \%$ Corroid tar in benzene

119, 103. Do. in Coalite tar

120, 104. Do. in Corroid tar

121, 105. Do. in Stockholm tar

122, 106. Do. in Shalco tar

123, 107. Cuprinol green for nets, tar added by makers

124, 108. Cuprinol colourless for ropes

125, 109. Cuprinol brown for wood .

126, 110. Shell canvas preservative .

127,111 . Shell wood preservative
Percentage strength after immersion.

$7 \frac{1}{2}$ months. 12 months.

.3320 lb., 1003300 lb., 100

$29 \quad 18$

$70 \quad$ Lost

$90,33 \quad 60,51$

$76,42 \quad 62,36$

$86,60 \quad 65,35$

105, 83 Lost

$94,80 \quad 97,92$

$89,58 \quad 97,91$

74 Lost

72 Lost

$76 \quad$ Lost

$56 \quad$ Lost

$98 \quad 81$

$72 \quad 66$

$73 \quad 64$

Table 5, for sisal, does not give as much information as it should owing to the fact that five ropes entirely disappeared though quite sound and apparently firmly fixed a fortnight previously. For this no explanation is forthcoming. It was unfortunate also that no oleate was included, for several of the resinates gave widely varying duplicates; this may have been occasioned by a weakening due to repeated bending by wave action or to imperfect penetration of preservative. It does not occur with the naphthenate series (Cuprinol and Shell). The best of the remaining ropes were those with 10 per cent copper resinate in Coalite or Corroid coal tar. The Cuprinol brown for wood is also good, due in its case chiefly to the presence of a specially good tar oil. For the sake of its lubricant action copper oleate in tar is to be preferred to copper resinate, or even a mixture of 5 per cent of each.

In order to settle a number of points raised in the foregoing experiments a series of 62 treatments with untreated control was tested in the tidal fish pond at Cawsand between 15/5/'34 and 28/3/35, namely, $10 \frac{1}{2}$ months. 
In order to get the results more rapidly a thinner rope was used, six strand yacht manila, approximately 0.6 inch in circumference ; breaking load about $300 \mathrm{lb}$. when new. This is about the size used as head line on certain types of net.

Immersion in preservative was for 24 hours unless otherwise stated. The results are shown in Tables 6-11.

Table 6 shows that for prolonged immersion cutch is almost useless, nor are either Olie's or Cunningham's methods to be recommended for ropes.

From Table 7 it may be gathered that Coalite neutral oil is the bestand fortunately the cheapest-solvent for copper oleate and copper resinate; paraffin oil, which has been used considerably in U.S.A. as being safer and cheaper than petrol, is unsatisfactory for oleate though rather better for resinate. The addition of tar is beneficial, as found in the earlier work also.

In Table 8 it may be seen that using $1 \mathrm{lb}$. per gallon ordinary coal tar is effective with oleate and resinate in benzene; but with Coalite tar an increase up to $2 \mathrm{lb}$. per gallon is an improvement, especially in oil A, with which smaller amounts of tar seem strangely ineffective.

Table 9 brings out the value of the Cuprinol ready mixed with tar and shows that it is permissible to lessen the cost by diluting with an equal volume of petrol. Since this is completely volatile the cost could be still further lessened, it appears, by using Coalite neutral oil instead. The brown Cuprinol, containing iron naphthenate and probably some zinc naph-, thenate also behaved better than expected due to an efficient tar oil. Both the Shell products are improved for ropes by the addition of tar.

\section{TABLE 6 .}

Cutch, probably mangrove with subsequent treatments. After $10 \frac{1}{2}$ months' immersion in fish pond open to sea. Rope six-strand yacht manila.

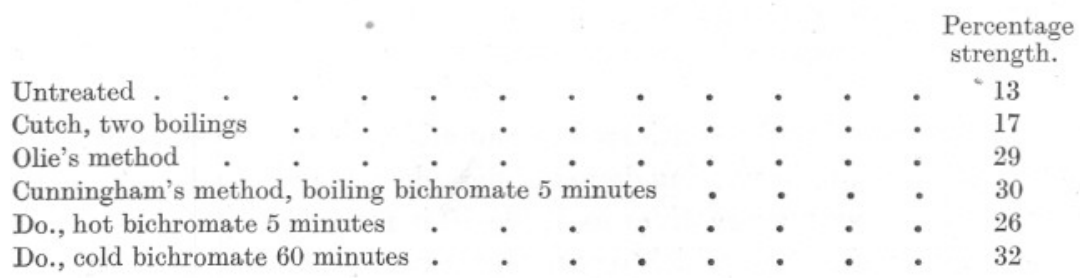

Both hot and boiling bichromate rotted the nets used. The untreated control is the same in Tables $6-11$. 


\section{TABLE 7.}

$1 \mathrm{lb}$. of copper oleate or resinate alone or with $1 \mathrm{lb}$. of coal tar (Corroid) in one gallon of solvent. The figures denote percentage strength after immersion for $10 \frac{1}{2}$ months, as in Tables 6-11.

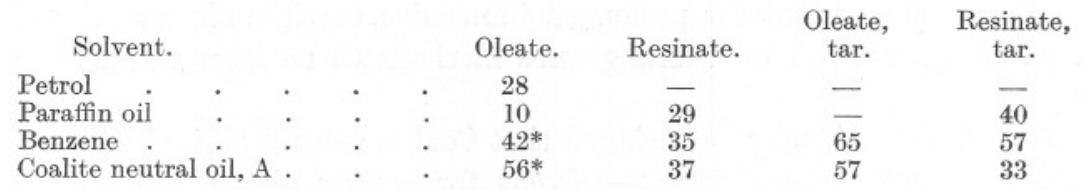

* With $1 \mathrm{lb}$. of copper resinate added per gallon these gave 33 per cent in benzene, but up to 65 per cent in oil $\mathrm{A}$; see also Table 1 .

\section{TABLE 8.}

$1 \mathrm{lb}$. of copper oleate or resinate with $1 \mathrm{lb}$. of a tar, in benzene or oil A, one gallon.

Tar.

Coal tar, Corroid

Coal tar, Coalite

Hardwood, Shalco

Softwood, Stockholm

$$
\begin{gathered}
\text { In } \\
\text { Oleate } \\
65^{*} \\
46 \dagger \\
35 \\
48
\end{gathered}
$$

In benzene.

$$
\text { Resinate. }
$$

57

33

30

43

\begin{tabular}{cc}
\multicolumn{2}{c}{ In oil A. } \\
Oleate. & Resinate. \\
$57 *$ & 33 \\
$42 \dagger$ & 25 \\
42 & 20 \\
43 & 20
\end{tabular}

* With 2 lb. of Corroid tar, per gallon, 67 per cent in benzene, 53 per cent in oil A.

$\dagger$ With 2 lb. of Coalite tar, per gallon, 60 per cent in benzene, up to 70 per cent in oil A.

\section{TABLE 9.}

Naphthenate preservatives.

No tar.

Cuprinol green for nets

Do. with equal volume of petrol

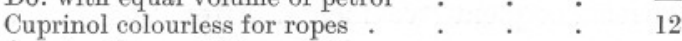

Cuprinol brown U for wood . . . . .

Shell canvas preservative (T.P.R. 78) . . 50

Shell wood preservative (T.P.R. 28)
With tar.

76 , mixed by makers

82

47, this has a tar oil*

63 , Corroid tar 10 per cent 33 - 67, Do.

* In consequence it cannot be painted over as can green Cuprinol.

The mixtures thus far considered do not add very greatly to the weight of the rope and are in varying degrees tolerably clean to handle. Turning now to the heavy preservatives in Table 10 it must be remembered that save for the wood tars, which dry well, they are all rather messy; this is a disadvantage for many purposes. But the heaviest tar, ordinary gas-works type, is excellent as a preservative, though the worst to handle. It is improved by copper oleate and copper resinate as shown in early net tests. Neither oleate nor resinate mixes well with Shalco tar and this is 
shown in the results, but by the use of a wood oil the makers have produced a blend which is quite useful. One of the most striking results is the great improvement in creosote oil, the quality used by Plymouth fishermen, by the addition of copper resinate, which also does well in the rather messy Coalite heavy oil ; copper oleate in Corroid tar appears to be slightly better, but such differences lie in the region in which cost is the final arbiter.

Table 11 summarizes the best results, including three from Table 10.

\section{TABLE 10.}

Heavyweight preservatives, tar or tar oils alone or with copper oleate or copper resinate, $1 \mathrm{lb}$. per gallon. Untreated 13 per cent after immersion.

Creosote oil .

Coal tar, Plymouth

Coal tar, Corroid.

Coalite heavy oil .

Coalite tar

Hardwood tar, Shalco

Shalco tar, export quality

Softwood tar, Stockholm
Tar. With oleate. With resinate.

$\begin{array}{lll}45 & 35 & 70 \\ 68 & - & - \\ 55 & 78 & 75 \\ \overline{55} & \overline{-} & 67 \\ 32 & 37 & 30 \\ \overline{43} & \overline{40} & 40 \\ & 48 & 63\end{array}$

\section{TABLE 11.}

Summary of best results in Tables 5-9. Untreated control

13 per cent.

Per cent.

Green Cuprinol for nets, tar formula, with equal volume of petrol $\quad$. $\quad$. $\quad 82$

Copper oleate 10 per cent in Corroid tar . . . . . . . . . . $\quad$. $\quad 78$

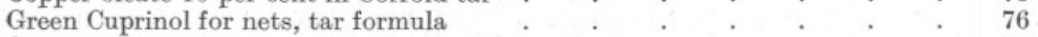

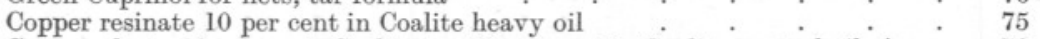

Copper oleate 10 per cent, Coalite tar 20 per cent in Coalite neutral oil, A . $\quad 70$

Copper resinate 10 per cent in creosote oil . . . . . . . 70

\section{SUMMARY.}

1. For the preservation of ropes the importance of the preservative against bacterial decay being also an internal lubricant for the rope fibres must be remembered.

2. Tests have been carried out for one year in sea-water, which was much contaminated by sewage at times, under Plymouth Pier and in cleaner water of a tidal basin outside Plymouth Sound Breakwater for $10 \frac{1}{2}$ months, using 2-inch and $0 \cdot 6$-inch ropes respectively; the latter was manila, the former were manila, hemp, sisal and coir.

3. The preservatives included cutch, cutch bichromate, cutch ammonia copper sulphate, coal tar distillates, including those of the Coalite process, 
also hardwood and softwood tars. The tars and tar oils were tried alone and mixed with copper soaps, naphthenate (Cuprinol and Shell products), oleate and resinate, also zinc and iron naphthenates (Cuprinol). The naphthenates and oleate are good lubricants.

4. Very good results were obtained with green Cuprinol containing tar and with 10 per cent copper oleate in a light coal tar; slightly inferior were 10 per cent copper resinate in Coalite heavy oil or in creosote oil as now used largely in Plymouth; also 10 per cent copper oleate with 20 per cent of Coalite tar in Coalite neutral oil, b.p. $100-245^{\circ}$ C., which is a very cheap solvent. All these maintained the thin manila rope at or above 70 per cent of its initial strength after $10 \frac{1}{2}$ months; the untreated control was down to 13 per cent.

5. Mixtures which maintained this rope at $60-69$ per cent of its initial strength were: copper oleate 10 per cent, coal tar 20 per cent in benzene; the same with 10 per cent of tar; copper oleate 10 per cent, Coalite tar 20 per cent in benzene; Shell wood preservative and Shell canvas preservative each with 10 per cent of coal tar; copper resinate 10 per cent in a light coal tar, Coalite tar or Stockholm tar ; copper oleate 10 per cent in Coalite tar ; 10 per cent each of copper oleate and copper resinate in Coalite neutral oil b.p. $100-245^{\circ} \mathrm{C}$. and a very heavy coal tar, which, however, was very messy also.

6. At the end of a year the 2-inch ropes immersed under the Pier were down to the following percentage strengths: hemp 0 , manila 0 , coir 6 , sisal 18. Sisal rope sinks in water at once, manila and hemp float when dry for a while, coir has considerable buoyancy.

7. Copper resinate 10 per cent in a light coal tar or in Coalite tar maintained the strength of 2-inch sisal rope under the Pier at 80-97 per cent of its original value for one year, save for one low figure, 58 per cent.

8. Used alone coal tars are superior to wood tars, but all are much improved by the addition of 10 per cent of copper oleate or copper resinate.

9. A dilute solution of sodium diethyldithiocarbamate is a useful reagent for testing whether ropes still give off copper after long immersion. The test is described in the accompanying paper on net preservation. 